\title{
22. PLIOCENE-PLEISTOCENE MAGNETOSTRATIGRAPHY OF SEDIMENTARY SEQUENCES FROM THE IRMINGER BASIN ${ }^{1}$
}

\author{
Koji Fukuma ${ }^{2}$
}

\begin{abstract}
Magnetostratigraphic data are presented for Pliocene-Pleistocene sedimentary sequences recovered at Sites 918 and 919 in the Irminger Basin. Results taken from archive halves of core sections with the shipboard pass-through magnetometer were examined by applying progressive alternating field demagnetization to 88 discrete samples on shore. Some possible polarity chrons, identified from the shipboard results, were recognized as artifacts caused by spurious secondary remanences. Based on downhole inclination variations, clear magnetic reversal patterns, correlative to the geomagnetic polarity time scale, could be defined for both sites, and it provides a firm chronostratigraphic framework for the Pliocene-Pleistocene sequences. At Site 918, a dramatic change in the sedimentation rate is bounded by a hiatus lasting for about $340 \mathrm{k} . \mathrm{y}$. from about 1.4 to $1.7 \mathrm{Ma}$. In the Irminger Basin, sedimentation rates may have fluctuated significantly in response to the growth and decay of glaciers in Greenland and changes in the depositional setting.
\end{abstract}

\section{INTRODUCTION}

One of the objectives of Ocean Drilling Program (ODP) Leg 152 is to clarify the glaciation history in Greenland. Based on shipboard analyses, it was concluded that substantial glaciation in Greenland began as early as $7 \mathrm{Ma}$ in the late Miocene (Larsen et al., 1994). The presence of several diamictite packages suggests that multiple glaciations occurred since the late Miocene. To address the glacial history in more details, a firm and detailed chronostratigraphic framework needs to be established for the sedimentary sequences.

Magnetostratigraphy provides a useful chronostratigraphic tool, especially when combined with biostratigraphy. For Sites 918 and 919, however, the shipboard magnetostratigraphic and biostratigraphic data are not fully compatible and in some cases are even contradictory to each other (Larsen, Saunders, Clift, et al., 1994). Several possible magnetic chrons and intermediate inclinations can be interpreted from the shipboard paleomagnetic data. In the present study, I examine the shipboard results, which were obtained from the archive halves of core sections at a single demagnetization step ( $25 \mathrm{mT})$, by applying progressive alternating field (AF) demagnetization for discrete samples. The detailed magnetic mineralogy and properties of the sedimentary sequences are discussed elsewhere (Fukuma, this volume).

The coring operation was accomplished with the hydraulic piston corer (APC) at Sites $918\left(63^{\circ} 5^{\prime} \mathrm{N}, 38^{\circ} 38^{\prime} \mathrm{W}, 110 \mathrm{~km}\right.$ from the coast of southeast Greenland) and $919\left(62^{\circ} 40^{\prime} \mathrm{N}, 37^{\circ} 28^{\prime} \mathrm{W}, 75 \mathrm{~km}\right.$ seaward of Site 918) down to 171.3 and $147.0 \mathrm{~m}$ below seafloor (mbsf), respectively. The recovery rates by the APC were $101.3 \%$ at Hole 918A and $100.1 \%$ and $102.1 \%$ for Holes 919A and 919B. At Hole 918A, below APC refusal, sediment cores drilled with the extended core barrel (XCB) down to $332.7 \mathrm{mbsf}$ did not provide a continuous sedimentary sequence (the recovery rate was 53.8\%). At Hole 918D, the rotary core barrel (RCB) coring proceeded into deeper sections, but the recovery rate was very poor above $500 \mathrm{mbsf}$. Thus, shore-

${ }^{1}$ Saunders, A.D., Larsen, H.C., and Wise, S.W., Jr. (Eds.), 1998. Proc. ODP, Sci. Results, 152: College Station, TX (Ocean Drilling Program).

${ }^{2}$ Rock Magnetism Laboratory, Department of Physics, Erindale College, University of Toronto, Mississauga, Ontario L5L IC6, Canada. (Present address: Deep Sea Research Department, Japan Marine and Technology Center [JAMSTEC], 2-15 Natsushima-cho, Yokosuka 237, Japan.) fukuma@jamstec.go.jp based analyses were restricted to samples from Holes 918A, 918B, 918C, 919A, and 919B spanning the approximate interval from late Pliocene to Holocene.

\section{METHODS}

The archive halves of the core sections were measured with a $2 \mathrm{G}$ pass-through cryogenic magnetometer on board. Remanent magnetization measurements were made at $10-\mathrm{cm}$ intervals before and after AF demagnetization, done on the $2 \mathrm{G}$ magnetometer track up to 25 $\mathrm{mT}$. Data were discarded from portions that suffered drilling disturbance or were soupy.

Discrete samples from the working halves of the core sections were collected by pushing custom-made $9-\mathrm{cm}^{3}$ plastic boxes into the sediments. The boxes are specially designed to take undisturbed sediment samples and to be nearly cubic shaped, contrary to the standard ODP boxes. Two samples were taken from each available core $(9.5$ $\mathrm{m})$. Shore-based remanence measurements were made with a Schonstedt spinner magnetometer at the paleomagnetics laboratory of Kyoto University. All the discrete samples were stepwise AF demagnetized at Kyoto University by a $2 \mathrm{G}$ Enterprises demagnetizer up to 70 or $90 \mathrm{mT}$, until the remanence intensity decreased to less than $10 \%$ of the initial value. Characteristic stable magnetization components were evaluated on orthogonal plots and equal-area projections of the demagnetization data, and the directions were calculated by the principal component analysis (Kirschvink, 1980). At Site 918, azimuthal orientations made by the tensor tool were available for some cores but were not used in this study because the high inclination values, associated with the high latitudes of Sites 918 and 919, made it possible to recognize the polarity pattern unambiguously.

To estimate the magnetic grain size, the ratios of anhysteretic susceptibility and low-field susceptibility $\left(\chi_{\mathrm{ARM}} / \chi\right)$ were determined for all discrete samples. Anhysteretic remanent magnetization was induced in a peak alternating magnetic field of $100 \mathrm{mT}$ coupled with a coaxial direct bias field of $0.05 \mathrm{mT}$ in the $2 \mathrm{G}$ Enterprises demagnetizer. Low-field susceptibility was measured with a Bartington susceptibility meter in the low-frequency mode $(0.47 \mathrm{kHz})$.

The geomagnetic polarity time scale of Ogg (1995) is adopted throughout this study. The ages of magnetic polarity chrons within the Pliocene-Pleistocene epochs are determined by astronomical tun- 
ing. These ages are very close to those calculated by Wei (1995), which is based on the systematic analysis of marine magnetic anomaly profiles done by Cande and Kent (1992).

\section{PALEOMAGNETIC RESULTS}

Examples of progressive AF demagnetization behaviors are presented on orthogonal plots and equal-area projections in Figure 1. Because the natural remanent magnetization (NRM) intensities before demagnetization are very high on the order of $10^{-1} \mathrm{~A} / \mathrm{m}$ (Table 1 ), samples can be reliably measured with the Schonstedt spinner magnetometer up to 70 or $90 \mathrm{mT}$.

AF demagnetization of some samples from Site 918 (Fig. 1A) and of most samples from Site 919 (Fig. 1B) shows a dominant single component remanence with a minor overprint. The stable component is easily identified as either a linear segment to the origin on orthogonal plots or clustered points on equal-area projections. The secondary overprint component is steeply downward and can be removed below $10 \mathrm{mT}$. Although the large positive inclination and low stabil-
A $918 \mathrm{~B}-3 \mathrm{H}-5,127-129 \mathrm{~cm}$

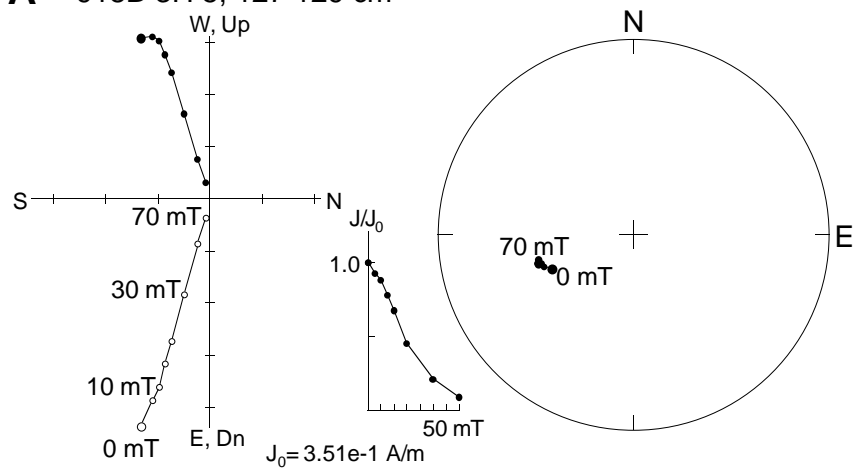

C $\quad 918 \mathrm{~A}-23 \mathrm{X}-3,90-92 \mathrm{~cm}$

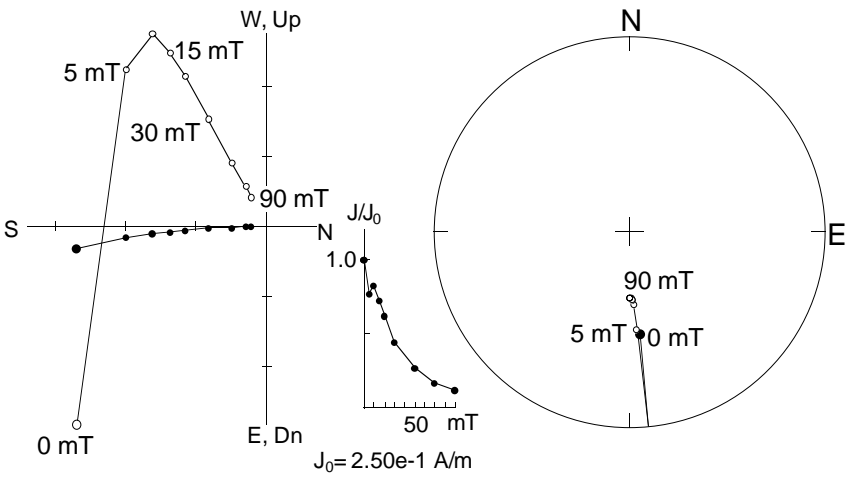

E $\quad$ 918A-27X-2, 58-60 cm

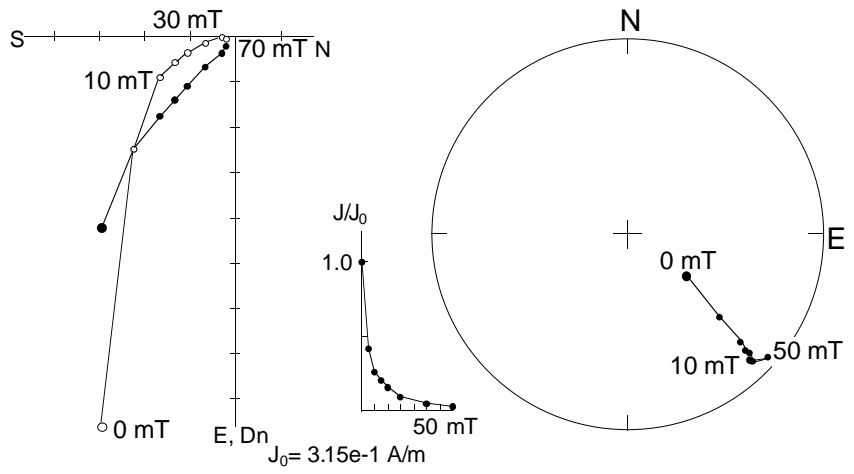

B $\quad 919 \mathrm{~A}-2 \mathrm{H}-3,80-82 \mathrm{~cm}$

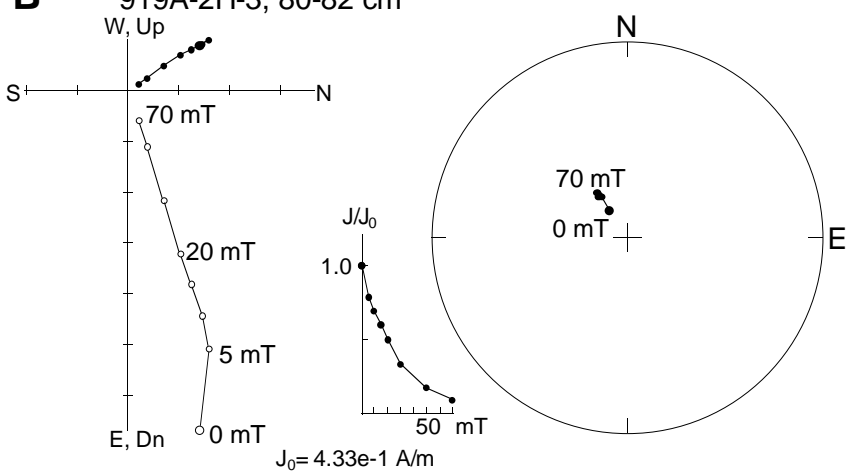

D $\quad 918 \mathrm{~A}-12 \mathrm{H}-2,102-104 \mathrm{~cm}$

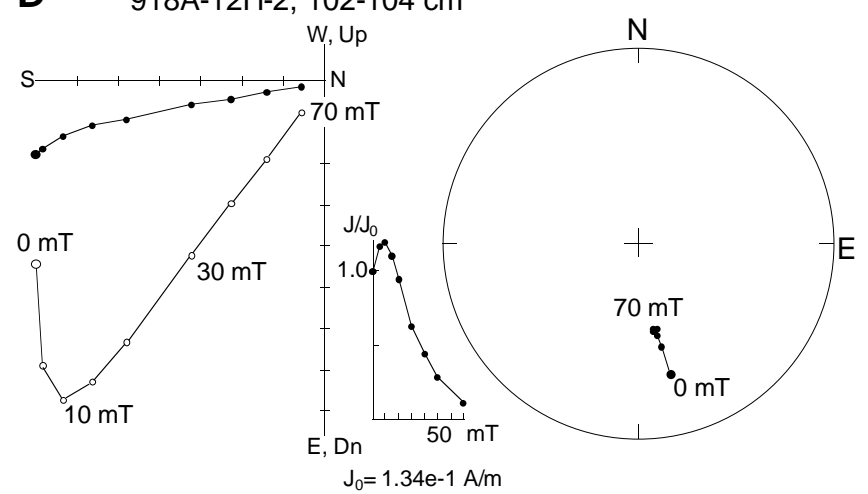

F $\quad 918 \mathrm{~A}-28 \mathrm{X}-4,6-8 \mathrm{~cm}$

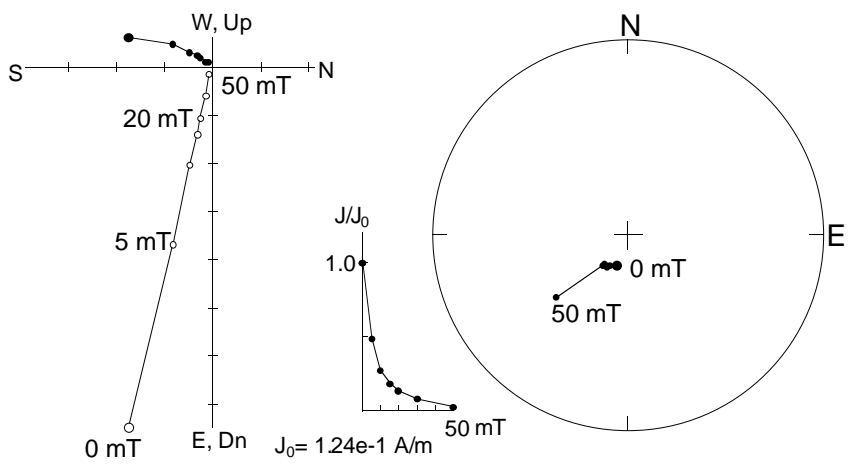

Figure 1. Orthogonal plots (left), intensity decay curves (middle), and equal-area projections (right) of magnetization behaviors during AF demagnetization. AB. Essentially single component remanences. C-D. Large secondary remanence components with characteristic stable remanences. E-F. Unsuccessful samples. Open and solid symbols on orthogonal plots represent the projected vector end points of magnetization on vertical and horizontal planes, respectively. Open and solid symbols on equal-area projections show the projected points on the upper and lower hemisphere, respectively. $\mathrm{J}_{0}$ denotes the remanence intensity before demagnetization. 
Table 1. Remanence data on discrete samples analyzed on shore for Sites 918 and 919.

\begin{tabular}{|c|c|c|c|c|c|c|c|c|c|c|c|c|c|}
\hline $\begin{array}{l}\text { Core, section } \\
\text { interval }(\mathrm{cm})\end{array}$ & $\begin{array}{l}\text { Depth } \\
\text { (mbsf) }\end{array}$ & $\begin{array}{c}\text { NRM } \\
\text { intensity } \\
(\mathrm{A} / \mathrm{m})\end{array}$ & $\begin{array}{c}\text { NRM } \\
\text { inclination } \\
\left(^{\circ}\right)\end{array}$ & $\begin{array}{c}\text { Stable } \\
\text { inclination } \\
\left({ }^{\circ}\right)\end{array}$ & $\begin{array}{l}\text { Stable } \\
\text { range } \\
(\mathrm{mT})\end{array}$ & $\chi_{\text {ARM }} / \chi$ & $\begin{array}{l}\text { Core, section } \\
\text { interval }(\mathrm{cm})\end{array}$ & $\begin{array}{l}\text { Depth } \\
\text { (mbsf) }\end{array}$ & $\begin{array}{c}\text { NRM } \\
\text { intensity } \\
(\mathrm{A} / \mathrm{m})\end{array}$ & $\begin{array}{c}\text { NRM } \\
\text { inclination } \\
\left(^{\circ}\right)\end{array}$ & $\begin{array}{c}\text { Stable } \\
\text { inclination } \\
\left(^{\circ}\right)\end{array}$ & $\begin{array}{c}\text { Stable } \\
\text { range } \\
(\mathrm{mT})\end{array}$ & $\chi_{\mathrm{ARM}} / \chi$ \\
\hline $152-918 \mathrm{~A}-$ & & & & & & & $37 X-2,107-109$ & 317.67 & $1.60 \mathrm{e}-1$ & -45.2 & -51.9 & $10-70$ & 5.51 \\
\hline $5 \mathrm{H}-3,61-63$ & 33.91 & $4.23 \mathrm{e}-1$ & 78.7 & 78.8 & $15-70$ & 7.92 & 152-918B- & & & & & & \\
\hline $\begin{array}{l}5 \mathrm{H}-6,27-29 \\
6 \mathrm{H}-2,46-48\end{array}$ & $\begin{array}{l}38.07 \\
41.76\end{array}$ & $6.07 \mathrm{e}-1$ & $\begin{array}{l}79.4 \\
74.8\end{array}$ & 76.2 & $10-70$ & $\begin{array}{l}6.12 \\
462\end{array}$ & $1 \mathrm{H}-1,77-79$ & 0.77 & $2.61 \mathrm{e}-1$ & 71.3 & 67.2 & $20-70$ & 8.65 \\
\hline $\begin{array}{l}6 \mathrm{H}-2,46-48 \\
6 \mathrm{H}-6,131-133\end{array}$ & $\begin{array}{l}41.76 \\
48.61\end{array}$ & $\begin{array}{l}4.55 \mathrm{e}-1 \\
190 \mathrm{e}-1\end{array}$ & $\begin{array}{r}74.8 \\
-26.3\end{array}$ & & & $\begin{array}{l}4.62 \\
6.89\end{array}$ & $1 \mathrm{H}-4,52-54$ & 5.02 & $2.37 \mathrm{e}-1$ & 80.3 & 80.5 & $20-70$ & 7.06 \\
\hline & $\begin{array}{l}48.61 \\
50.84\end{array}$ & $\begin{array}{l}1.90 \mathrm{e}-1 \\
5.84 \mathrm{e}-1\end{array}$ & $\begin{array}{r}-26.3 \\
66.5\end{array}$ & $\begin{array}{l}40.9 \\
60.3\end{array}$ & $\begin{array}{l}10-70 \\
15-90\end{array}$ & $\begin{array}{l}6.89 \\
6.55\end{array}$ & $2 \mathrm{H}-3,64-66$ & 10.44 & $2.14 \mathrm{e}-1$ & 77.1 & 78.3 & $10-70$ & 7.13 \\
\hline $\begin{array}{l}7 \mathrm{H}-2,4-6 \\
7 \mathrm{H}-4,98-100\end{array}$ & $\begin{array}{l}50.84 \\
54.78\end{array}$ & $\begin{array}{l}5.84 \mathrm{e}-1 \\
3.17 \mathrm{e}-1\end{array}$ & $\begin{array}{r}66.5 \\
-71.4\end{array}$ & $\begin{array}{r}60.3 \\
-71.3\end{array}$ & $\begin{array}{l}10-90 \\
20-70\end{array}$ & $\begin{array}{l}0.53 \\
4.47\end{array}$ & $2 \mathrm{H}-5,118-120$ & 13.98 & $3.44 \mathrm{e}-1$ & 65.9 & 65.4 & $20-90$ & 8.01 \\
\hline & 61.19 & $4.16 \mathrm{e}-1$ & -60.3 & -64.7 & $10-70$ & $\begin{array}{l}4.41 \\
6.97\end{array}$ & $3 \mathrm{H}-2,109-111$ & 18.89 & $2.59 \mathrm{e}-1$ & 77.3 & 70.3 & $15-70$ & 7.11 \\
\hline $8 \mathrm{H}-5,103-105$ & 65.83 & $1.98 \mathrm{e}-1$ & -33.4 & -48.7 & $30-90$ & 5.59 & $3 \mathrm{H}-5,127-129$ & 23.57 & $3.51 \mathrm{e}-1$ & & 48.1 & $10-70$ & 6.83 \\
\hline $9 \mathrm{H}-3,56-58$ & 71.86 & $3.35 \mathrm{e}-1$ & -69.4 & -72.7 & $15-90$ & 4.82 & $152-918 \mathrm{C}-$ & & & & & & \\
\hline 9H-6, 91-93 & 76.71 & $5.85 \mathrm{e}-1$ & -62.9 & -65.6 & $10-90$ & 6.65 & $1 \mathrm{H}-3,113-115$ & 29.93 & $2.55 \mathrm{e}-1$ & 81.2 & 77.3 & $20-70$ & 7.95 \\
\hline $10 \mathrm{H}-2,70-72$ & 80.00 & $1.25 \mathrm{e}-1$ & 6.6 & -72.4 & $20-90$ & 5.48 & $1 \mathrm{H}-6,60-62$ & 33.90 & $3.91 \mathrm{e}-1$ & 64.3 & 65.1 & $10-90$ & 4.97 \\
\hline $\begin{array}{l}10 \mathrm{H}-6,40-42 \\
11 \mathrm{H}-2\end{array}$ & 85.70 & $6.33 \mathrm{e}-1$ & 71.7 & 56.5 & $20-70$ & 6.00 & $152-919 \mathrm{~A}-$ & & & & & & \\
\hline $\begin{array}{l}11 \mathrm{H}-2,96-98 \\
11 \mathrm{H}-6,40-42\end{array}$ & $\begin{array}{l}89.76 \\
95.20\end{array}$ & $4.05 \mathrm{e}-2$ & $\begin{array}{l}74.6 \\
694\end{array}$ & & & $\begin{array}{l}6.55 \\
7.82\end{array}$ & $1 \mathrm{H}-1,44-46$ & 20.44 & $5.85 \mathrm{e}-1$ & 82.2 & 60.3 & $20-90$ & 6.80 \\
\hline $11 \mathrm{H}-6,40-42$ & 95.20 & $8.35 \mathrm{e}-1$ & 69.4 & 69.2 & $15-70$ & 7.82 & $1 \mathrm{H}-4,48-50$ & 4.98 & $3.05 \mathrm{e}-1$ & 66.2 & 66.8 & $15-90$ & 8.83 \\
\hline $12 \mathrm{H}-2,102-104$ & 99.32 & $1.34 \mathrm{e}-1$ & 31.5 & 52.3 & $20-70$ & 5.71 & $2 \mathrm{H}-3,80-82$ & 11.80 & $4.33 \mathrm{e}-1$ & 76.0 & 69.5 & $20-70$ & $\begin{array}{l}8.83 \\
6.67\end{array}$ \\
\hline $12 \mathrm{H}-6,20-22$ & 104.50 & $2.76 \mathrm{e}-1$ & 2.6 & -1.2 & $15-50$ & 8.28 & $2 \mathrm{H}-5,84-86$ & 14.84 & $4.07 \mathrm{e}-1$ & 86.8 & 84.8 & $15-70$ & 0.07 \\
\hline $13 \mathrm{H}-2,70-72$ & 108.50 & $1.99 \mathrm{e}-1$ & 13.9 & 36.3 & $20-90$ & 6.11 & & & & & & & 6.31 \\
\hline $13 \mathrm{H}-4,129-131$ & 112.09 & $1.52 \mathrm{e}-1$ & 32.3 & 49.4 & $20-90$ & 5.99 & $3 \mathrm{H}-3,92-94$ & 21.42 & $4.04 \mathrm{e}-1$ & 73.7 & 71.1 & $20-70$ & 7.48 \\
\hline $14 \mathrm{H}-2,80-82$ & 118.10 & $9.26 \mathrm{e}-2$ & 23.4 & -67.5 & $15-90$ & 5.61 & $3 \mathrm{H}-6,11-13$ & 25.11 & $1.57 \mathrm{e}-1$ & 68.7 & 67.4 & $20-90$ & 6.55 \\
\hline $14 \mathrm{H}-5,41-43$ & 122.21 & $5.63 \mathrm{e}-2$ & -6.5 & -22.9 & $20-70$ & 6.27 & $4 \mathrm{H}-2,59-61$ & 29.09 & $1.61 \mathrm{e}-1$ & 54.3 & 66.6 & $20-70$ & 7.24 \\
\hline $15 \mathrm{H}-2,80-82$ & 127.60 & $6.98 \mathrm{e}-2$ & 13.0 & -69.2 & $15-40$ & 6.14 & $4 \mathrm{H}-6,21-23$ & 34.71 & $5.19 \mathrm{e}-1$ & 84.0 & 83.5 & $20-70$ & 8.39 \\
\hline $15 \mathrm{H}-4,80-82$ & 130.60 & $1.97 \mathrm{e}-1$ & 43.9 & -75.6 & $15-70$ & 5.58 & $5 \mathrm{H}-2,44-46$ & 38.44 & $3.30 \mathrm{e}-1$ & 81.0 & 78.0 & $15-70$ & 6.13 \\
\hline $16 \mathrm{H}-2,48-50$ & 135.28 & $6.60 \mathrm{e}-2$ & 19.0 & & & 5.15 & $5 \mathrm{H}-5,85-87$ & 43.35 & $3.55 \mathrm{e}-1$ & 66.5 & 58.8 & $20-90$ & 7.85 \\
\hline $16 \mathrm{H}-5,4-6$ & 139.34 & $7.16 \mathrm{e}-1$ & 24.1 & -46.3 & $20-70$ & 6.39 & $6 \mathrm{H}-1,120-122$ & 47.20 & $9.22 \mathrm{e}-1$ & 53.0 & 52.2 & $15-70$ & 6.67 \\
\hline $17 \mathrm{H}-1,84-86$ & 143.64 & $2.81 \mathrm{e}-1$ & 32.4 & -55.8 & $10-90$ & 6.51 & $6 \mathrm{H}-5,125-127$ & 53.25 & $3.04 \mathrm{e}-1$ & 75.2 & 75.2 & $20-70$ & 6.73 \\
\hline $17 \mathrm{H}-4,57-59$ & 147.87 & $2.92 \mathrm{e}-1$ & 56.9 & 30.9 & $15-70$ & 6.41 & $7 \mathrm{H}-3,63-65$ & 59.13 & $5.81 \mathrm{e}-1$ & 85.8 & 74.2 & $20-70$ & 6.08 \\
\hline $18 \mathrm{H}-2,125-127$ & 155.05 & $3.02 \mathrm{e}-1$ & 69.9 & -4.4 & $20-70$ & 5.48 & $7 \mathrm{H}-5,105-107$ & 62.55 & $3.29 \mathrm{e}-1$ & 75.7 & 75.2 & $20-70$ & 7.17 \\
\hline $18 \mathrm{H}-5,61-63$ & 158.91 & $5.51 \mathrm{e}-1$ & 67.4 & -44.1 & $15-70$ & 4.74 & $8 \mathrm{H}-3,62-64$ & 68.62 & $6.66 \mathrm{e}-1$ & 80.5 & 75.2 & $20-70$ & 6.11 \\
\hline $19 \mathrm{H}-1,130-132$ & 163.10 & $2.48 \mathrm{e}-1$ & 57.0 & -64.2 & $20-70$ & 6.09 & 9H-2, 91-93 & 76.91 & $4.97 \mathrm{e}-1$ & 75.5 & 67.3 & $10-70$ & 6.59 \\
\hline $19 \mathrm{H}-4,104-106$ & 167.34 & $4.72 \mathrm{e}-1$ & -10.2 & -58.9 & $15-70$ & 6.29 & $9 \mathrm{H}-6,20-22$ & 82.20 & $5.52 \mathrm{e}-1$ & 81.7 & 76.5 & $10-70$ & 5.94 \\
\hline $20 X-4,44-46$ & 176.24 & $1.15 \mathrm{e}-1$ & 35.6 & -54.7 & $10-70$ & 4.67 & $10 \mathrm{H}-3,51-53$ & 87.51 & $7.52 \mathrm{e}-1$ & 74.6 & 72.6 & $20-70$ & 6.85 \\
\hline $21 X-2,128-130$ & 184.28 & $5.39 \mathrm{e}-1$ & 79.5 & -29.4 & $15-50$ & 4.18 & $10 \mathrm{H}-6,55-57$ & 92.05 & $4.35 \mathrm{e}-1$ & 63.5 & 61.9 & $20-70$ & 7.17 \\
\hline $23 X-3,90-92$ & 203.70 & $2.50 \mathrm{e}-1$ & 46.0 & -61.2 & $15-90$ & 5.99 & 152-919B- & & & & & & \\
\hline $23 \mathrm{X}-5,44-46$ & 206.24 & $3.56 \mathrm{e}-1$ & 76.2 & -55.0 & $15-70$ & 5.36 & $3 \mathrm{H}-5,51-53$ & 96.51 & $5.22 \mathrm{e}-1$ & 76.7 & 71.1 & $15-70$ & 7.58 \\
\hline $24 \mathrm{X}-2,83-85$ & 211.03 & $3.62 \mathrm{e}-1$ & 80.6 & -68.8 & $15-90$ & 6.18 & $3 \mathrm{H}-7,45-47$ & 99.45 & $9.98 \mathrm{e}-1$ & 79.7 & 68.9 & $15-70$ & 6.70 \\
\hline $24 \mathrm{X}-6,58-60$ & 216.78 & $5.13 \mathrm{e}-2$ & 30.1 & -88.5 & $15-90$ & 5.86 & $4 \mathrm{H}-3,50-52$ & 103.00 & $2.86 \mathrm{e}-1$ & 72.4 & 72.3 & $15-70$ & 7.79 \\
\hline $25 X-2,68-70$ & 219.78 & $1.04 \mathrm{e}-1$ & -36.0 & -73.7 & $15-70$ & 5.79 & $4 \mathrm{H}-5,16-18$ & 105.66 & $2.18 \mathrm{e}-1$ & 78.6 & 70.3 & $10-70$ & 4.27 \\
\hline $25 X-6,70-72$ & 225.80 & $1.70 \mathrm{e}-1$ & -57.9 & -64.1 & $20-70$ & 6.23 & $5 \mathrm{H}-2,9-11$ & 110.59 & $6.37 \mathrm{e}-1$ & 84.9 & 82.5 & $15-90$ & 5.28 \\
\hline $26 \mathrm{X}-2,120-122$ & 229.20 & $2.85 \mathrm{e}-1$ & -62.4 & -73.8 & $\begin{array}{l}15-70 \\
20-70\end{array}$ & $\begin{array}{l}5.73 \\
5.78\end{array}$ & $5 \mathrm{H}-5,11-13$ & 115.11 & $3.34 \mathrm{e}-1$ & 70.9 & 71.1 & $15-70$ & 7.38 \\
\hline $26 \mathrm{X}-5,79-81$ & 233.29 & $1.80 \mathrm{e}-1$ & 46.5 & -79.4 & $20-70$ & 5.78 & $6 \mathrm{H}-1,67-69$ & 119.17 & $5.12 \mathrm{e}-1$ & 75.3 & 76.6 & $20-70$ & 7.58 \\
\hline $27 X-2,58-60$ & 237.28 & $3.15 \mathrm{e}-1$ & 59.2 & & & 6.17 & $6 \mathrm{H}-3,80-82$ & 122.30 & $9.54 \mathrm{e}-2$ & -48.5 & -71.2 & $10-70$ & 6.02 \\
\hline $27 X-4,87-89$ & 240.57 & $1.86 \mathrm{e}-1$ & -27.1 & -59.4 & $15-70$ & 6.72 & $6 \mathrm{H}-5,57-59$ & 125.07 & $4.43 \mathrm{e}-1$ & -54.6 & -68.3 & $15-70$ & 6.17 \\
\hline $28 \mathrm{X}-2,49-51$ & 246.09 & $2.64 \mathrm{e}-1$ & -39.3 & -64.4 & $10-70$ & 6.33 & $7 \mathrm{H}-3,81-83$ & 131.81 & $2.72 \mathrm{e}-1$ & -40.7 & -50.8 & $30-70$ & 6.70 \\
\hline $28 \mathrm{X}-4,6-8$ & 248.66 & $1.24 \mathrm{e}-1$ & 76.1 & & & 2.13 & $7 \mathrm{H}-5,113-115$ & 135.13 & $5.56 \mathrm{e}-1$ & -52.8 & -67.0 & $20-70$ & 5.31 \\
\hline $31 X-1,91-93$ & 271.51 & $2.71 \mathrm{e}-1$ & 77.9 & -75.3 & $20-70$ & 5.64 & $8 \mathrm{H}-3,51-53$ & 141.01 & $2.80 \mathrm{e}-1$ & -55.3 & -61.4 & $10-70$ & 6.83 \\
\hline $\begin{array}{l}31 X-4,56-58 \\
33 X-1,98-100\end{array}$ & $\begin{array}{l}275.66 \\
289.38\end{array}$ & $\begin{array}{l}2.75 \mathrm{e}-1 \\
3.59 \mathrm{e}-1\end{array}$ & $\begin{array}{l}-47.2 \\
-40.9\end{array}$ & $\begin{array}{l}-52.7 \\
-69.9\end{array}$ & $\begin{array}{l}15-70 \\
10-90\end{array}$ & $\begin{array}{l}5.18 \\
5.82\end{array}$ & $8 \mathrm{H}-6,88-90$ & 145.88 & $8.49 \mathrm{e}-1$ & -57.2 & -56.4 & $15-70$ & 7.16 \\
\hline
\end{tabular}

ity are suggestive of viscous remanence origin, the relative declinations between stable and secondary components vary from sample to sample. I discard the possibility of viscous remanence for the origin of secondary components. Probably, the steeply downward secondary components were induced during the drilling operation, as frequently reported on ODP cores.

Many samples from Site 918 exhibit two component remanences with a large steeply inclined normal (Fig. 1C) and reversed (Fig. 1D) secondary component. AF demagnetization usually to $20 \mathrm{mT}$ or sometimes to $30 \mathrm{mT}$, which is comparable to $25 \mathrm{mT}$ adopted for shipboard measurements, was necessary to isolate the stable component (Table 1). In spite of the presence of a large secondary component, the stable component can be clearly defined on orthogonal plots and equal-area projections. The normal secondary component is probably of drilling-induced remanence origin similar to minor secondary components as shown in Figures 1A and 1B. The reversed secondary component may also be induced during the drilling operation, as reported for some hard rock samples from ODP cores. However, it should be noted that the shipboard results for the interval of 98-115 mbsf at Site 918 show large negative inclination values even after AF demagnetization at $25 \mathrm{mT}$ (Fig. 2A). Meanwhile, the discrete Sample 152-918A-12H-2, 102-104 cm (99.32 mbsf), exhibits positive inclination before AF demagnetization, and the reversed overprint is almost removed below $10 \mathrm{mT}$ (Fig. 1D). This sample was measured about two months after the end of Leg 152. Although the plastic box was sealed with tape, the sample had somehow dried up by the mea- surement time. The reversed overprint may have been partly erased due to oxidation of magnetic sulfides (e.g., greigite, pyrrhotite) during sample storage (Fukuma, this volume).

I could find stable components through progressive AF demagnetization for all but five out of a total of 88 discrete samples from Sites 918 and 919 . Some of the unsuccessful samples showed curvilinear segments even in demagnetization steps larger than $20 \mathrm{mT}$ (Fig. 1E). I interpret this behavior as the result of an overlap between AF coercivity spectra of the reversed stable and normal secondary (probably drilling-induced) components. Some samples possess a stable remanence with an anomalously low inclination (e.g., Sample 152-918A12H-6, 20-22 cm; Table 1). These samples also show similar behavior as shown in Figure 1E, but the segments at high demagnetization steps are indistinguishable from a line on the orthogonal plots. Although the stable component may not be relevant to the primary depositional remanence, I include the inclination values in Table 1 to avoid overediting.

Another unsuccessful sample (Sample 152-918A-28X-4, 6-8 cm) showed a linear segment, but the AF coercivity was relatively low $(<50 \mathrm{mT})$ (Fig. 1F). The $\chi_{\mathrm{ARM}} / \chi$ of 2.13 for this sample is quite low, compared to other samples from Sites 918 and 919 (Table 1). The value of 2.13 corresponds to a grain size of several microns if it is assumed to be magnetite (Bloemendal et al., 1992). Such a large grain size is probably due to coarse-grained ice-rafted debris observed in lithologic Unit IC of Site 918 (Larsen, Saunders, Clift, et al., 1994) and resulted in complete overprinting. 
Figure 2. Plots of inclinations with depth below seafloor and interpreted magnetic polarity sequences for Sites 918 (A) and 919 (B). Dots show the inclinations obtained by AF demagnetization at $25 \mathrm{mT}$ on archive halves of core sections on board, and open circles show the inclinations of stable magnetizations obtained through progressive AF demagnetization for discrete samples on shore. Crosses indicate the positions of discrete samples that did not have stable magnetizations. The letters $\mathrm{J}, \mathrm{O}$, and $\mathrm{R}$ at the polarity column denote the Jaramillo, Olduvai, and Reunion subchrons, respectively.

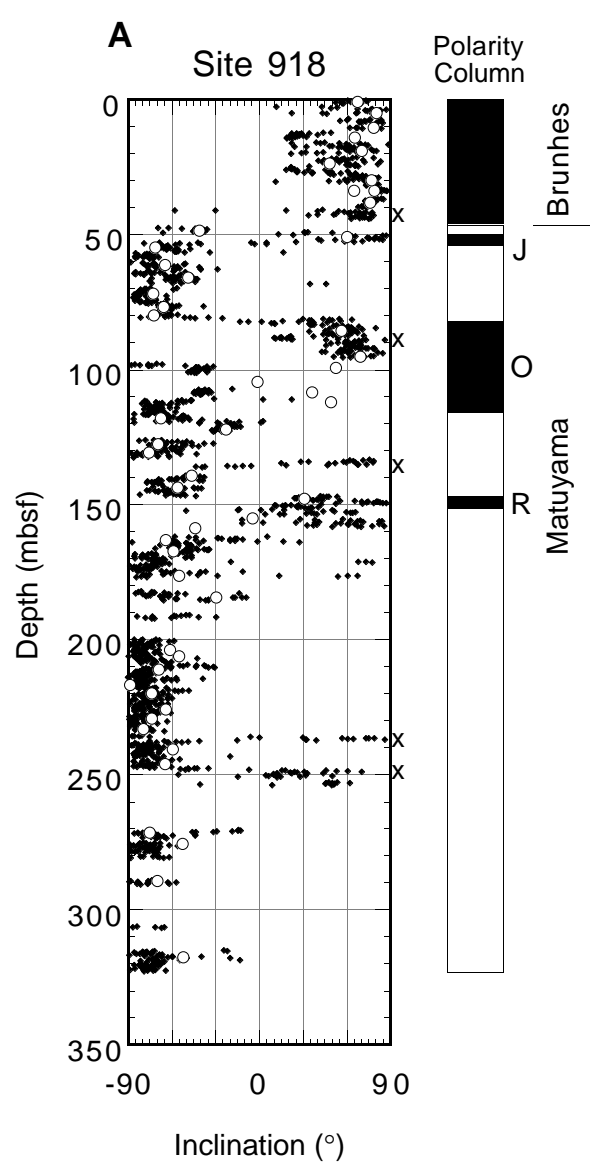

B

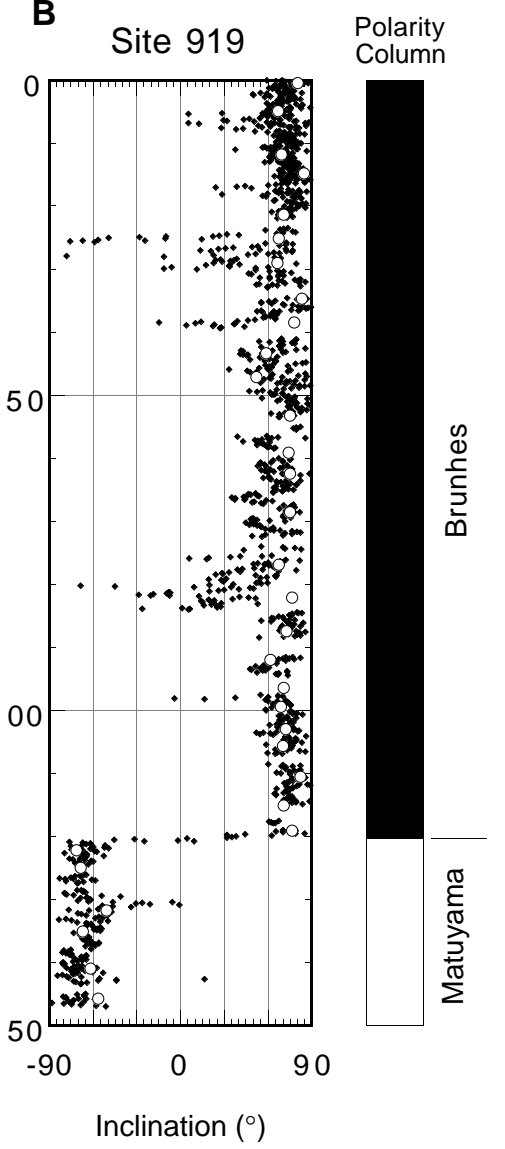

Inclination values, which were obtained from shipboard measurements after $\mathrm{AF}$ demagnetization at $25 \mathrm{mT}$ and were derived from stable components of discrete samples after progressive AF demagnetization on shore, are plotted with depth in Figure 2. To identify magnetic polarity chrons, I have taken a conservative approach: at least one discrete sample with a stable remanence is necessary to identify a magnetic chron. Determination of the depth of a polarity boundary is primarily based on the shipboard data, but is based only on discrete samples for the intervals where the shipboard data are inconsistent to the data of discrete samples. Thus, I obtained a clear but slightly different magnetic polarity sequence from that obtained on board for Sites 918 and 919 (Larsen, Saunders, Clift, et al., 1994).

At Site 918, the inclination data consist of shipboard data for Hole 918A and shore-based data for Holes 918A, 918B, and 919C (Fig. 2A). Some possible magnetic chrons apparent on the shipboard data are discarded based on the shore-based AF demagnetization results. For example, Sample 152-918A-27X-2, 58-60 cm (237.28 mbsf), does not show a stable component due to the overlapping AF coercivity of stable and secondary remanences (Fig. 1E). Single step demagnetization on board failed to detect such an overlapping coercivity and gave a spurious normal polarity chron. Also there appear some isolated intermediate inclination values in the shipboard data. Even in the shore-based data, there still remain intermediate inclinations. As discussed above, however, these values should be regarded with caution and may be due to overlapping coercivity spectra.

By confirming a reversely magnetized interval just above $50 \mathrm{mbsf}$ at Site 918, I can separate the Jaramillo subchron from the overlying Brunhes chron (Fig. 2A). The Olduvai subchron is extended to a deeper section by eliminating the reversed secondary remanences of discrete samples. There seemingly exist two separate Reunion subchrons on the shipboard data. It is reasonable that two separate Reunion subchrons can be found when one considers the high sedimen- tation rate for the lithologic Unit IB of Site 918 (see "Sedimentation Rates" section, this paper). However, because no discrete sample was available for the interval corresponding to the lower Reunion subchron, only the upper boundary of the upper Reunion subchron is defined. No normal polarity zone was identified below the Reunion subchron down to the bottom of Hole 918A (332.7 mbsf). This suggests that the deepest sediment of Hole 918A is still younger than the Matuyama/Gauss boundary of $2.60 \mathrm{Ma}$ (Ogg, 1995).

For Site 919, the inclination data consist of shipboard and shorebased data for Holes 919A and 919B (Fig. 2B). Neither of the two possible reversed chrons (at about 25 and $80 \mathrm{mbsf}$ ) within a normal polarity interval (0-120 mbsf), which appeared in the shipboard data, are recognized in the shore-based data. All discrete samples from this normal polarity interval showed stable normal magnetizations through AF demagnetization. In fact, even before AF demagnetization these discrete samples possessed normal magnetizations. The reversed magnetizations observed in the shipboard data are probably of secondary origin, and were lost during sample storage before measurements were made on shore. Since no reversed polarity interval was identified above $120 \mathrm{mbsf}$ and no hiatus was observed in the visual core descriptions and the seismic stratigraphy, I have no choice other than to place the Brunhes/Matuyama boundary at about 120 mbsf (Fig. 2B).

\section{SEDIMENTATION RATES}

Table 2 lists the polarity boundaries to the nearest decimeter identified at Sites 918 and 919. The interpreted age-depth relations are shown in Figure 3 based on the magnetostratigraphic controlling points alone. For Site 919, the tie line between the present seafloor 
Table 2. Depths of magnetic polarity boundaries observed at Sites 918 and 919.

\begin{tabular}{lccc}
\hline Polarity boundary & $\begin{array}{c}\text { Age } \\
\text { (Ma) }\end{array}$ & $\begin{array}{c}\text { Site } 918 \\
\text { depth } \\
\text { (mbsf) }\end{array}$ & $\begin{array}{c}\text { Site 919 } \\
\text { depth } \\
\text { (mbsf) }\end{array}$ \\
\hline $\begin{array}{l}\text { Brunhes/Matuyama } \\
\text { Upper Jaramillo }\end{array}$ & 0.78 & 45.9 & 120.3 \\
$\begin{array}{l}\text { Lower Jaramillo } \\
\text { Upper Olduvai }\end{array}$ & 1.99 & 49.0 & \\
Lower Olduvai & 1.79 & 52.9 & \\
Upper Reunion & 1.95 & 11.0 & \\
\hline
\end{tabular}

and the Brunhes/Matuyama boundary gives the high sedimentation rate of $15.4 \mathrm{~cm} / \mathrm{k} . \mathrm{y}$.

A seismic reflection profile suggests that a local erosional unconformity lies at about $65 \mathrm{~m}$ below the present seafloor at Site 918 (Larsen, Saunders, Clift, et al., 1994). This unconformity probably corresponds to an erosional contact found at $71.1 \mathrm{mbsf}$ in a recovered sediment core from Hole 918A. Hence, I fitted the polarity boundary points after dividing them into two intervals below and above 71.1 mbsf. For both intervals the controlling points are quite well fitted by linear regression (Fig. 3). That gives dramatically different sedimentation rates for these two intervals divided by the hiatus: $5.0 \mathrm{~cm} / \mathrm{k} . \mathrm{y}$. for the upper interval (Unit IA) and $18.7 \mathrm{~cm} / \mathrm{k} . \mathrm{y}$. for the lower interval (Unit IB). The hiatus is estimated to have continued for 0.34 m.y. beginning from $1.73 \mathrm{Ma}$ to $1.39 \mathrm{Ma}$. The high sedimentation rate of $18.7 \mathrm{~cm} / \mathrm{k} . \mathrm{y}$. for the lower interval (below $71.1 \mathrm{mbsf}$ ) is concordant with the average rate of $19.9 \mathrm{~cm} / \mathrm{k} . \mathrm{y}$. for the entire Pliocene section estimated from the shipboard biostratigraphy (Larsen, Saunders, Clift, et al., 1994). However, if extrapolating the regression line into the interval older than the Reunion subchron, the line reaches the Matuyama/Gauss boundary (2.60 Ma) near the lithostratigraphic boundary between Units IB and IC (236.0 mbsf). It should therefore be expected that normal polarity (Gauss) remanent magnetizations are seen throughout most of Unit IC. However, no normal magnetic interval is present within the recovered core below the Reunion subchron down to the deepest part of Hole 918A (332.7 mbsf) (Fig. 2A). Core recovery was very poor in this interval (the recovery rate was less than $50 \%$ in Unit IC) and thus normal intervals may have been missed. According to Wei (this volume), the boundary between early and late Pliocene (3.58 Ma) may be within the lower part of Unit IC (280 mbsf) and hence, if correct, the Gauss normal chron has been missed. Though this is possible, it is not very likely. Another possibility is that Unit IC, including a 70-m package of diamictites, was accumulated at an ultra high rate in the early Matuyama chron $(<2.60$ $\mathrm{Ma}$ ). The present data cannot confirm or reject this interesting notion. However, I conclude that the stratigraphic controls provided by the magnetostratigraphic and biostratigraphic data strongly suggest that sedimentation rates fluctuated significantly, possibly in response to the growth and decay of glaciers in Greenland and the changes in the depositional setting (Clausen, this volume).

\section{SUMMARY}

To establish magnetostratigraphy for the Pliocene-Pleistocene sedimentary sequences recovered from Sites 918 and 919 in the Irminger Basin, I conducted progressive alternating field demagnetization on 88 discrete samples to examine the results obtained on core sections with the shipboard pass-through magnetometer. I found that some possible magnetic chrons appearing on the shipboard data were artifacts caused by spurious secondary remanences. After eliminating these artificial magnetic chrons, I could obtain clearer magnetic reversal patterns correlative to the geomagnetic polarity time scale for both sites. The following are the calculated sedimentation rates based on magnetostratigraphy.

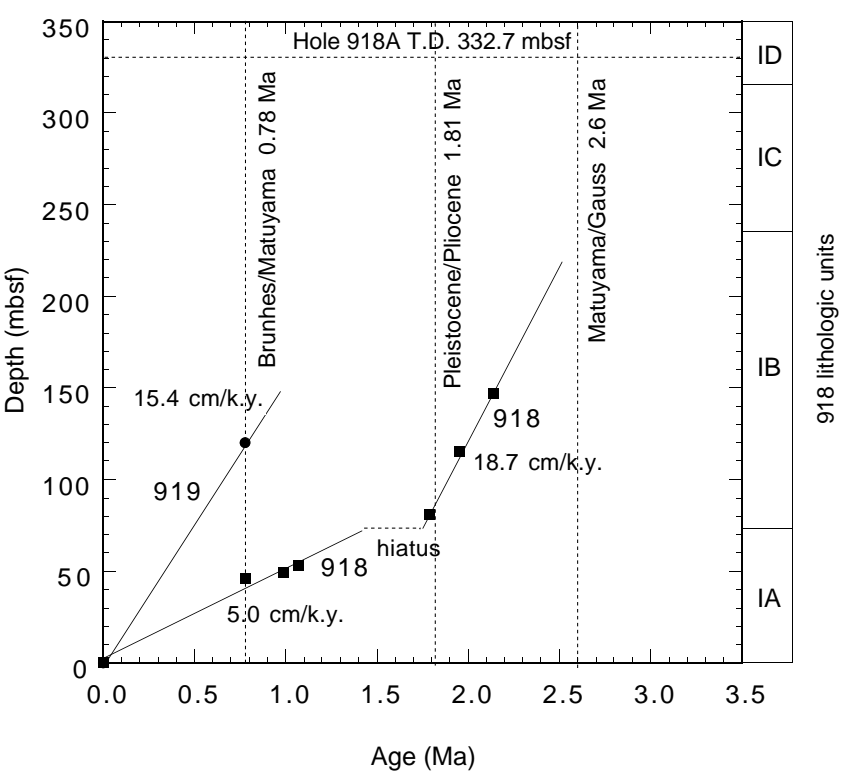

Figure 3. Age vs. depth relationship for Sites 918 and 919.

1. At Site 918 , the sedimentation rate dramatically decreased from $18.7 \mathrm{~cm} / \mathrm{k} . \mathrm{y}$. to $5.0 \mathrm{~cm} / \mathrm{k} . \mathrm{y}$. bounded by a hiatus spanning 1.39 and 1.73 Ma.

2. At Site 919 , the high sedimentation rate of $15.4 \mathrm{~cm} / \mathrm{k} . \mathrm{y}$. was obtained for the Brunhes chron.

\section{ACKNOWLEDGMENTS}

I would like to thank D. Vandamme and J. Ali for the measurements on board and M. Torii for the use of the facilities at Kyoto University. This research was supported by a Fellowship of the Japan Society for the Promotion of Science for Japanese Junior Scientists and a Grant-in-aid for scientific research of Ministry of Education of Japan (No. 04649702).

\section{REFERENCES}

Bloemendal, J., King, J.W., Hall, F.R., and Doh, S.-J., 1992. Rock magnetism of late Neogene and Pleistocene deep-sea sediments: relationship to sediment source, diagenetic processes, and sediment lithology. J. Geophys. Res., 97:4361-4375.

Cande, S.C., and Kent, D.V., 1992. A new geomagnetic polarity time scale for the Late Cretaceous and Cenozoic. J. Geophys. Res., 97:1391713951.

Kirschvink, J.L., 1980. The least-squares line and plane and the analysis of paleomagnetic data. Geophys. J. R. Astron. Soc., 62:699-718.

Larsen, H.C., Saunders, A.D., Clift, P.D., et al., 1994. Proc. ODP, Init. Repts., 152: College Station, TX (Ocean Drilling Program).

Larsen, H.C., Saunders, A.D., Clift, P.D., Beget, J., Wei, W., Spezzaferri, S., and the ODP Leg 152 Scientific Party, 1994. Seven million years of glaciation in Greenland. Science, 264:952-955.

Ogg, J.G., 1995. Magnetic polarity time scale of the Phanerozoic. In Ahrens, T.J. (Eds.), Global Earth Physics: A Handbook of Physical Constants. Am. Geophys. Union, 240-270.

Wei, W., 1995. Revised age calibration points for the geomagnetic polarity time scale. Geophys. Res. Lett., 22:957-960.

Date of initial receipt: 10 August 1995

Date of acceptance: 26 July 1996

Ms 152SR-224 